\section{The Effect of Primary School Students' Writing Attitudes and Writing Self-Efficacy Beliefs on Their Summary Writing Achievement}

Pınar Bulut ${ }^{a}$

\author{
Received: 14 August 2017 \\ Revised: $\quad 06$ Sept. 2017 \\ Accepted: 18 Sept. 2017 \\ ISSN: 1307-9298 \\ Copyright (C) IEJEE \\ www.iejee.com
}

DOI: 10.26822/iejee.2017236123

\begin{abstract}
In this study, the effect of writing attitude and writing self-efficacy beliefs on the summarization achievement of the $4^{\text {th }}$ grade primary school students was examined using the structural equation modeling. The study employed the relational survey model. The study group constructed by means of simple random sampling method is comprised of 335 fourth grade primary school students. In the collection of the research data, "Writing Self-efficacy Scale (Güneş, Kuşdemir and Bulut, 2017)", "Writing Attitude Scale (Can, 2016)" and "Summary Evaluation Form for Narrative Texts" (Bulut, 2013) were used. For the current study, the constructed hypothesis is "writing attitude and writing self-efficacy positively and significantly affect writing achievement" and thus a model was formed. In the analysis of the data, SPSS 22 and AMOS 22.0 program packages were used. As a result of the study, it was found that writing attitude and writing self-efficacy beliefs are highly correlated to each other and writing attitude and writing self-efficacy beliefs directly and significantly affect summary writing.
\end{abstract}

Keywords: Attitude, self-efficacy, writing attitude, writing self-efficacy, summary writing.

\section{Introduction}

Writing is an important expressive language skill that the individual performs using symbols that refer to voices. Writing is the most recently acquired skill that begins to be learned by reading during the formal education process. According to Güneş (2007), writing starts with the review of the information that is structured in the brain. Writing comes into being as a result of organization of the information to be selected by considering writing purpose, method, subject and limitations through various mental processes such as sorting, classifying, establishing relations, criticizing, estimating, analyzing and synthesizing and then expression of this organized information with letters, syllables, words and sentences.

Graham (2006; cited by Graham, Hebert, Sandbank \& Harris, 2014) states that writing is a preferred tool for students to express what they know in today's classrooms. On the other hand, according to Troia and Graham (2003), writing is one of the most complicated literacy activities for adults and children.

Though writing is viewed to be a difficult language skill, there are many benefits incurred by the acquisition of this skill. Writing is a skill necessary for critical thinking, learning and expression. Students who develop effective writing skills during school years have a significant advantage over those who do not in their later life (Graham \& Perin, 2007). In addition, because writing is interwoven with mental processes, it helps students to expand their thinking, organize their knowledge, use language, enrich their knowledge, and develop their mental dictionaries (Güneş, 2007). In addition to these benefits, the development of writing skills promotes the aesthetic sensitivity of students and then written expression starts to be perceived as an artistic endeavor and feeling rather than a science (Ungan, 2007).

There are many factors affecting the individual's writing achievement. They can be cognitive, affective or physical factors. The most important affective factors affecting writing achievement are attitude and self-efficacy belief.

Attitude involves an assessment of an object, person or event on a continuum extending from negative to positive and makes us prone to behaving in a certain way in the face of that object, person or event (Plotnik, 2009).

Göçer (2014) points out that the interests, desires and attitudes of each individual are not the same for the writing skills which are very important in the communication and social life of individuals and stresses that one of the factors that affect the written expression achievement of individuals and cause them to move away from writing is their attitude towards writing. Variables such as education, family environment, and personal characteristics are influential in the emergence of different attitudes towards writing (Akaydın and Kurnaz, 2015).

Graham, Berninger, and Fan (2007) define the writing attitude as an effective regulation that causes the author to feel happy or unhappy during the writing activity. According to Graham et al. (2007), students' writing attitudes affect their writing achievement.

Another affective factor affecting writing achievement is self-efficacy belief. Self-efficacy beliefs are defined as "people's judgments about their skills to organize and

a Correspondence details: Gazi University, Faculty of Education, Department of Elementary Education, Yenimahalle, Ankara/Turkey. E-mail: pnrbulut06@gmail.com (P. Bulut) 
perform acts that are required to achieve certain types of performance" (Bandura, 1986; cited by Schunk, 1989). Senemoğlu (2005) defines the concept of self-efficacy as the individual's own judgment, belief about himself/herself regarding the extent to which he/she will be successful in overcoming difficult situations to be confronted with in the future. Self-efficacy is a key mechanism in social cognitive theory that assumes that achievements are based on interactions between behaviors, personal factors, and environmental conditions (Schunk, 2003). Self-efficacy is a key concept for ensuring student participation and encouraging learning (Graham, Harris, Bartlett, Popadopoulou \& Santoro, 2014). Jinks and Lorsbach (2003) argue that self-efficacy may be a powerful tool for educators to meet the learning needs of students. According to Schunk (2003), at the beginning of learning activities, there is a sense of self-efficacy for students to achieve their goals. The student's self-evaluation of his/her learning process helps to protect self-efficacy and motivation.

The self-efficacy beliefs affect students' performance by influencing the choices made, the effort spent and the perseverance and anxiety felt in the face of distress (Pajares\& Valiante, 1997). If the individual has low selfefficacy belief, he/she may feel insufficient in the relevant work or activity. Therefore, students' self-efficacy beliefs need to be nurtured. Senemoğlu (2005) makes some suggestions to the teachers in order to strengthen their students' self-efficacy perceptions. These are teaching in such a way as to meet the individual needs of students, conducting various activities so that each student can get engaged in, using cooperation-based teaching approaches and avoiding approaches based on the comparison of students. In Akar (2008), some suggestions are made to improve self-efficacy. Some of them are general and some others are directly related to writing. These are, feedback, setting goal, modeling, strategy use, assigning challenging tasks, positive high expectations, teaching methods, successful learning experiences, right to choice and teacher attitude.

There are different strategies and techniques that readers can apply at different stages of the reading process in order to make the reading process more efficient and to obtain the highest level of meaning from the reading. One of them is writing summary. Summarizing refers to the reader's finding the main idea in the text, removing unnecessary details and shortening the text without distorting the structure of the text and flow of thought with his/her own words and sentences by using some strategies (Bulut, 2013). Summarization is a multifaceted process that requires a variety of prerequisite skills of which finding the main idea is the most important and that enhances students' comprehension and cognitive abilities (Williams, 2007).

Summary writing is not a random writing exercise. Therefore, it should be taught to students by teachers. According to Anderson, Suzanne and Babadoğan (1991), in this teaching process, teachers must first choose a short and easy text. Later, longer texts can be used as students gain experience in summarizing. Summary writing must first begin with texts in the narrative type.
A qualified summary must have certain characteristics in terms of content, form, language and narrative. In addition, Brown, Day and Jones (1983) emphasize that there are five basic rules for producing a good summary. These are removal of insignificant information, removal of unnecessarily repeated information, generalization, selection of the topic sentence and originality. These rules can be regarded as summarizing strategies.

There is research showing that there is a relationship between students' attitudes towards writing, writing selfefficacy and writing achievement. Graham, Berninger and Fan (2007), in their study investigating the relationship between the primary school students' writing achievement and writing attitude, concluded that age factor is important and the third-grade students are more successful in writing than the first-grade students. In the same study, the girls were found to have more positive attitudes towards writing than the boys. However, gender was not found to be significantly influential on writing achievement. The researchers stated that differences in the students' writing attitudes and behaviors led to individual differences in writing achievement. They found that the students having more positive attitudes towards writing had higher writing achievement than their counterparts with weaker attitudes towards writing. Demir (2013) found a positive, medium and statistically significant correlation between the secondary school $8^{\text {th }}$ grade students' creative writing competence and writing self-efficacy perceptions. It was stated that in general students with higher self-efficacy have better creative writing skills. Baştuğ (2015), in a study focusing on writing and affective factors affecting it, found that writing disposition and attitude significantly and positively affect writing achievement; writing attitude and disposition significantly and negatively affect writer's block; writer's block negatively and significantly affects writing achievement. It was found that writer's block has the greatest effect on writing achievement, followed by writing disposition and writing attitude.

The level of schooling was also found to be effective on writing attitude. Yıldız and Kaman (2016), found that while the primary school students' attitude towards writing is significantly higher than that of the secondary school students, their attitudes do not vary significantly depending on gender.

Writing achievement depends on writing self-efficacy and writing attitude. For achievement, self-efficacy level should be high. Moreover, the attitude developed towards writing directly affects achievement. The current study investigated the direct effect of writing attitude and writing self-efficacy on writing achievement. To this end, the following model was constructed.

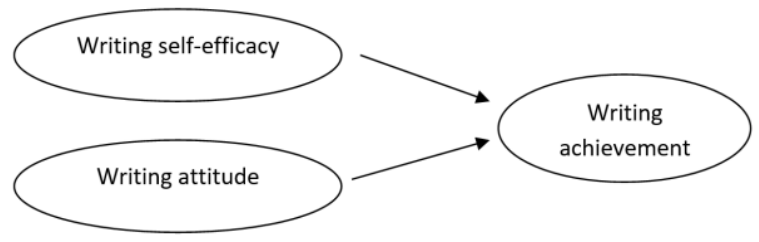

Figure 1. Writing Model 


\section{Methodology}

\section{Research Model}

The current study was designed in the relational survey model, as it aimed to determine the relationship between the primary school fourth grade students' writing selfefficacy, writing attitude and summary writing achievement. This relationship was investigated by using the structural equation modeling. "Relational survey models are the models aiming to determine the existence of covariance between two or more variables and/or its degree." (Karasar, 2000, p. 81).

\section{Participants}

The universe of the study consists of the primary school fourth grade students in the city of Yozgat. In order to determine the sampling, the schools with medium socioeconomic level from among the secondary schools in the city were determined and two of them were randomly selected to make up the sampling. A total of 335 students participated in the study (Girls: 160, Boys: 175).

\section{Process}

During the data collection process of the study, the students were asked to complete two scales (writing attitude scale, writing self-efficacy scale) and to write the summaries of two narrative texts. In the selection of the narrative texts, the following procedure was followed: First 8 narrative texts from two textbooks decided to be used with 4th graders by the Ministry of National Education were selected. As narrative texts are easier to summarize than informative texts (Anderson et. al 1991), the study only focused on narrative texts. Then the selected texts were sent to five experts working in the field of Turkish and language teaching. The experts examined the texts in terms of their suitability for the level of students. As a result of this examination, only three texts on which all the experts agreed were selected. Then the researcher selected two of them and asked the students to summarize them. During the summary writing process, the texts were given to the students for them to see and look at the texts as long as they wanted. Nothing more was said to the students. The students were given 40 minutes for each summary writing. The students were clearly explained how to fill in the scales on sample questions not included in the scales.

\section{Measure}

The data of the study were collected by using the Writing Self-efficacy Scale, Writing Attitude Scale, Summary Evaluation Form for Narrative Texts and Personal Information Form. The results obtained from the reliability and validity studies of the scales are given below:

Writing Self-efficacy Scale. The Writing Self-Efficacy Scale was developed by Güneş, Kuşdemir and Bulut (2017) in order to determine the writing self-efficacy status of primary school fourth grade students. The scale was prepared in the form of a three-point Likert scale (suitable for me, a little suitable for me, not suitable for me). However, considering the age and grade level of the students, next to these three response options, facial expressions reflecting their meanings were also placed to be able to obtain more reliable and valid data. The lowest score to be taken from the Writing Self-efficacy Scale is 10 and the highest score is 30. During the development of the scale, exploratory and confirmatory factor analyses were conducted to establish the validity of the scale. As a result of exploratory factor analysis, the three factors of the scale were found to be explaining $52.8 \%$ of the total variance and this is an acceptable level. For the whole of the scale, Cronbach Alpha value was calculated to be .69. Before and after the rotation, the total value of the variance explained by the factors did not change. As a result of confirmatory factor analysis, this three-factor construct was found to have adequate goodness-of-fit indices (CMIN/DF = 2.14; $G F I=.964 ; \mathrm{AGFI}=.938 ; \mathrm{CFI}=.914 ; \mathrm{RMR}=.014 ; \mathrm{RMSEA}=.057)$. The Writing Self-efficacy Scale was administered to a group having similar characteristics to the ones possessed by the study group before it was used for the current study and the Cronbach Alpha value was calculated to be .72 for the whole scale on the collected data from this piloting application.

Summary Evaluation Form for Narrative Texts. In the current study, "The Summary Evaluation Form for Narrative Texts" developed by Bulut (2103) to evaluate students' summaries written for narrative texts was used. The Summary Evaluation Form consists of 23 items and 4 sub-dimensions. These sub-dimensions are content, form, text structure and language and expression. In the measurement of each criterion in the form, a three-point scaling was used as adequate $=2$ points, partially adequate $=1$ point and inadequate $=0$ point. In order to establish the content validity of the Summary Evaluation Form, the researchers sought expert opinions and in addition to this, used Lawshe technique for the content validity. In line with this technique, for each item in the Summary Evaluation Form, the content validity ratio (KGO) was calculated. And for each item, a value higher than 0.62 was found (for 10 experts). Moreover, the content validity ratio calculated for the Summary Evaluation Form for Narrative Texts is 0.93. Therefore, all the items were included in the form. For the reliability of the Summary Evaluation Form, 50 summaries were evaluated by the researcher and by another researcher and the correlation coefficient between the results of the two researchers was calculated to be $r=0.82$. The high and significantly positive correlation between these two evaluations indicates that the evaluation form yields reliable measurements.

\section{Data Analysis}

The data obtained from the administration of the Writing Self-efficacy and Attitude Scales and the summary texts written by the students were scored and the obtained results were entered into the computer environment. The collected data were analyzed by using SPSS 22.0 and AMOS 22.0 statistical programs.

\section{Results}

In the current study, the effect of writing self-efficacy and writing attitude on students' writing achievement was examined. In this section, findings obtained in the current study are presented. First, the descriptive statistics and correlations related to the variables of the study are given. 
Table 1. Correlation results related to the variables

\begin{tabular}{lccc}
\hline & $\begin{array}{c}\text { Writing } \\
\text { attitude }\end{array}$ & $\begin{array}{c}\text { Writing } \\
\text { self- } \\
\text { efficacy }\end{array}$ & $\begin{array}{c}\text { Summary } \\
\text { writing } \\
\text { score }\end{array}$ \\
\hline Correlation $(r)$ & & & \\
\hline $\begin{array}{l}\text { Writing } \\
\text { attitude }\end{array}$ & 1 & .87 & .72 \\
\hline $\begin{array}{l}\text { Writing self- } \\
\text { efficacy }\end{array}$ & .87 & 1 & .53 \\
\hline $\begin{array}{l}\text { Summary } \\
\text { writing score }\end{array}$ & .72 & .53 & 1 \\
\hline
\end{tabular}

As can be seen in Table 1, there is a positive and very high correlation between writing attitude and writing selfefficacy, and between writing self-efficacy and summary writing. Moreover, there is a positive and high correlation between writing self-efficacy and summary writing.

In the study the hypothesis "writing attitude and writing self-efficacy significantly and positively affect summary writing achievement" was tested. In order to determine whether there is such an effect, the structural equation modeling was used. As a result of the analysis, the fit values were found to be as follows: $\left(\chi^{2} / s d=2.15\right.$; RMSEA= 0.043; $\mathrm{GFI}=0.90 ; \mathrm{AGFI}=0.90 ; \mathrm{CFI}=0.92)$. These values show that there is a good and acceptable fit. Thus, the hypothesis of the study was supported. That is, the effect of writing attitude and self-efficacy on primary school fourth grade students' summary writing achievement is significant and positive.

\section{Discussion}

Self efficacy is a concept that is influential on social and motor skills and affecting students' learning and achievement performance (Schunk, 1989). When an individual is asked to perform tasks for which his/her motivation is low, the concept of self-efficacy comes to the fore as a critical concept. Writing is one of these tasks (Bruning, Dempsey, Kauffman, McKim \& Zumbrunn, 2013). Writing is a complex and demanding task that is posing motivational challenges for even talented writers. Conceptually, self-efficacy refers to some certain abilities. Writing requires many skills, strategies and knowledge such as self-regulation. Thus, for some certain aspects of writing, self-efficacy may change (MacArthur, Philippakos \& Graham, 2015).

Writing is a difficult task for people from any age group (Troia\&Graham, 2003) because it is not just a mechanical task but also a mental activity. Particularly students at school do not like writing or experience difficulty in writing tasks. This leads to the formation of negative attitudes towards writing and decreasing self-efficacy belief.

From among the affective factors influential on the writing skill, the most important ones are self-efficacy and attitude. When the relevant literature is reviewed, it is seen that there are some studies investigating the effect of students' writing self-efficacy and attitude on writing achievement (Pajares \& Valiante, 1997; Graham, Berninger \& Fan, 2007; Demir, 2013; Baştuğ, 2015). Karadağ and Kayabaşı (2013) conducted a study on pre-service teachers and found that the main reasons for their reluctance to write are lack of self-confidence (40.2\%) and lack of motivation (16.1\%).

Summary writing is a process of finding the main idea on the basis of the source text, removing unnecessary details and shortening by using one's own words. However, while doing this, the structure and flow of thoughts in the source text should not be distorted. As a result of the current study exploring the effect of writing self-efficacy and attitude on writing achievement through the structural equation modeling, the established hypothesis was supported. That is, the effect of writing self-efficacy and attitude on writing achievement is positive and significant. When the findings of the current study are compared to the findings reported by similar studies in the literature, they seem to support each other. Baştuğ (2015) conducted a study on writing and affective factors affecting it and found that writing disposition and attitude significantly and positively affect writing achievement; writing attitude and disposition significantly and negatively affect writer's block; writer's block significantly and negatively affect writing achievement. The greatest effect on writing achievement comes from writer's block, writing disposition and writing attitude, respectively. In this study, a high correlation was found between writing self-efficacy and writing attitude. Demir (2013) found a positive, moderate and statistically significant correlation between the primary school $8^{\text {th }}$ graders' creative writing and self-efficacy perception. Moreover, a positive, moderate and significant correlation was found between the students' free writing skills and self-efficacy perception. A positive, low and significant correlation was found between the primary school $8^{\text {th }}$ graders' topic-based written expression scores and selfefficacy perception. This finding indicates that the students' topic-based expression does not directly affect their writing self-efficacy perception. A positive, moderate and significant correlation was found between the primary school $8^{\text {th }}$ grade students' creative writing scores and the writing self-efficacy scale's sub-dimension of written expression skills. Considering this significant correlation, it can be argued that the creative writing skills of the students whose written expression skill perceptions are high are developed. The research findings of Bruning et al. (2013) show that writing ideation and self-regulation selfefficacy to be significantly more strongly related to liking writing than conventions self-efficacy but less related than conventions self-efficacy to writing assessment scores. All 3 writing self-efficacy dimensions showed moderate positive correlations with self-reported writing performance.

In the current research, while examining the effect of writing self-efficacy and writing attitude on summary writing achievement, the students in the study group were asked to write the summaries of only narrative texts. Further research can be designed to explore narrative and informative texts together. Moreover, the study group of the current research consists of students from medium socio-economic level. Similar research can be conducted on students attending schools with different socioeconomic levels. 


\section{References}

Akar, C. (2008). Öz yeterlik inancı ve ilkokuma yazmaya etkisi. Uşak Üniversitesi Sosyal Bilimler Dergisi, 1(2), 185-198.

Akaydın, Ş., \& Kurnaz, H. (2015). Lise öğrencilerine yönelik yazma tutum ölçeği: geçerlik ve güvenirlik çalışması. Mustafa Kemal University Journal of Graduate School of Social Sciences, 12( 32), 246-261.

Anderson, V., Suzanne, H., \& Babadoğan, C. (1991). Özetlemenin öğrencilere öğretimi. Ankara Üniversitesi Eğitim Bilimleri Fakültesi Dergisi, 24(2), 587-594.

Baştuğ, M. (2015). Effects of primary school fourth-grade students' attitude, disposition and writer's block on writing success. Education and Science, 40 (180), 73-88.

Brown, A.L., Day, J.D., \& Jones, R.S. (1983). The development of plans for summarizing texts. Child Development, 54, 968-979.

Bruning, R. , Dempsey, M., Kauffman, D.F., McKim, C., \& Zumbrunn, S.(2013). Examining dimensions of selfefficacy for writing. Journal of Educational Psychology, 105(1), 25-38.

Bulut, P. (2013). ilköğretim 5. sınıf öğrencileri ve ögretmenlerinin özetleme stratejilerinin değerlendirilmesi: Türkçe dersi örneği [The evaluation of summarizing strategies of the primary school 5th grade students and teachers: Turkish lesson example ]. Unpublished Doctoral Dissertation, Gazi Üniversitesi, Ankara.

Can, B. (2016). Öz düzenlemeli strateji geliştirmeye dayalı öğretim modelinin hikâye yazma becerilerini geliştirmeye etkisi. [ The effect of education model based on self-regulated strategy development on improving story writing skills]. Unpublished Doctoral Dissertation, Gazi Üniversitesi, Ankara.

Demir, T. (2013). İlköğretim öğrencilerinin yaratıcı yazma becerileri ile yazma özyeterlik algısı ilişkisi üzerine bir çalışma. International Journal of Turkish Literature Culture Education, 2(1), 84-114.

Göçer A. (2014). Yazma tutum ölçeğinin (ytö) Türkçeye uyarlanması: Geçerlik ve güvenirlik çalışması. Kastamonu Üniversitesi Kastamonu Eğitim Dergisi, 22(2), 515-524.

Graham, S., Berninger, V., \& Fan, W. (2007). The structural relationship between wrting attitude and writing achivement in first and third grade students. Contemporary Educational Psychollogy, 32, 516-536.

Graham, S., Hebert, M., Sandbank, M.P., \& Harris, K.R. (2016). Assessing the writing achievement of young struggling writers: Application of generalizability theory. Learning Disability Quarterly, 39 (2), 72-82.

Graham, S., \& Perin, D. (2007). A meta-analysis of writing instruction for adolescent students. Journal of Educational Psychology, 99(3), 445-476.

Güneş, F. (2007). Türkçe öğretimi ve zihinsel yapılandırma. Ankara: Nobel Yayın Dağıtım.
Güneş, F., Kuşdemir, Y., \& Bulut, P. (2017). Psychometric features of the writingself-efficacy scale. International Journal of Social Science, $58,101-114$

Jinks, J., \& Lorsbach, A. (2003). Introduction: Motivation and self-efficacy belief. Reading \& Writing Quarterly, 19(2), 113-118.

Karadağ, R., \& Kayabaşı, B. (2013). Neden yazı yazmıyoruz? Sınıf öğretmeni adaylarının yazmayı engelleyen etmenlere ilişkin görüşleri. Erzincan Üniversitesi Eğitim Fakültesi Dergisi, 15(1), 1-32.

Karasar, N. (2000). Bilimsel araştırma yöntemi. Ankara: Nobel Yayın Dağıtım.

MacArthur,C.A., Philippakos, Z.A., \& Graham, S. (2015). Multicomponent measure of writing motivation with basic college writers. Learning Disability Quarterly, 39(1), 31-43.

Pajares, F. \& Valiante, G. (1997). Predictive utility and causal influence of the writing self-efficacy beliefs of elementary students. Paper presented at the annual meeting of the American Educational Research Association. New York, US. Retrived from https://files.eric.ed.gov/fulltext/ED394144.pdf

Plotnik, R. (2009). Psikolojiye giriş. İstanbul: Kaknüs Yayınları.

Schunk, D. H. (1989). Self-efficacy and achievement behaviors. Educational Psychology Review, 1( 3), $173-$ 208.

Schunk, D. H. (2003). Self-efficacy for reading and writing: Influence of modeling, goal setting, and selfevaluation. Reading and Writing Quarterly, 19, 159-172.

Senemoğlu, N. (2005). Gelişim, öğrenme ve ögrretim. Kuramdan uygulamaya. Ankara: Gazi Kitabevi.

Troia, G. A., \& Graham, S. (2003). The consultant's corner: "Effective writing instruction across the grades: what every educational consultant should know". Journal of Educational and Psychological Consultation, 14(1), 7589.

Ungan, S. (2007). Yazma becerisinin geliştirilmesi ve önemi. Erciyes Üniversitesi Sosyal Bilimler Enstitüsü Dergisi, $23,461-472$

Williams, A. R. (2007). The effects of summarization Instruction on the comrehension and metacognitive abilities of sixth grade students in a title / middle school. Ph.D. Thesis. University of Alabama, Alabama.

Yıldız, M. ve Kaman, Ş. (2016). Illköğretim (2-6. sınıf) öğrencilerinin okuma ve yazma tutumlarının incelenmesi. Türkiye Sosyal Araştırmalar Dergisi, 2, 507-522. 
This page is intentionally left blank

www.iejee.com 